\title{
The smile in endogenous depression
}

\section{Seymour Spencer}

Leon demonstrated the pure endogenousness of cyclical depression. Assistant master at a preparatory school, he was incapable of work, suicidal and needed admission during depressive episodes. But he happened to be well between bouts and out of phase for relapse, when a new managerial regime took over-and promptly sacked him; even this extreme circumstance precipitated no mood change, except one of such militant anger that he negotiated for himself extremely favourable terms of pension and domicile.
Months later, the next depressive bout necessitated readmission. It was in the 1950 s, when England became involved in Far Eastern strife. Leon was depressed to near suicide; on a ward round he looked the picture of misery. But utter depression could not obliterate his puckish sense of humour. "What is the matter today?", I asked. "I think", he replied, "I think I'm suffering from Korea".

Seymour J. G. Spencer, Consulting Psychiatrist, Oxfordshire Health Authority 